\title{
Inherited predisposition to colorectal cancer: towards a more complete picture
}

\author{
Emma Short, ${ }^{1}$ Laura E Thomas, ${ }^{1}$ Joanna Hurley, ${ }^{2}$ Sian Jose, ${ }^{3}$ Julian R Sampson ${ }^{1}$
}

- Additional material is published online only. To view please visit the journal online (http://dx.doi.org/10.1136/ jmedgenet-2015-103298).

${ }^{1}$ Institute of Cancer and Genetics, Cardiff University, Heath Park Campus, Cardiff, UK

${ }^{2}$ Department of

Gastroenterology, Cwm Taf University Health Board, Prince Charles Hospital, Merthyr Tydfil, UK

${ }^{3}$ Institute of Medical Genetics, Cardiff and Vale Health Board, Cardiff, UK

\section{Correspondence to}

Professor Julian R Sampson, Institute of Cancer and Genetics, Cardiff University, Heath Park Campus, Cardiff CF14 4XN, UK:

sampson@cardiff.ac.uk

Received 3 June 2015 Revised 22 July 2015 Accepted 28 July 2015
To cite: Short $\mathrm{E}$,

Thomas LE, Hurley J, et al. J Med Genet Published Online First: [please include Day Month Year] doi:10.1136/ jmedgenet-2015-103298

\section{ABSTRACT}

Colorectal carcinoma $(C R C)$ is the third most common cancer worldwide. Hereditary factors are important in $15 \%-35 \%$ of affected patients. This review provides an update on the genetic basis of inherited predisposition to CRC. Currently known genetic factors include a group of highly penetrant mutant genes associated with rare mendelian cancer syndromes and a group of common low-penetrance alleles that have been identified through genetic association studies. Additional mechanisms, which may underlie a predisposition to CRC, will be outlined, for example, variants in intermediate penetrance alleles. Recent findings, including mutations in POLE, POLD1 and NTHL1, will be highlighted, and we identify gaps in present knowledge and consider how these may be addressed through current and emerging genomic approaches. It is expected that identification of the missing heritable component of CRC will be resolved through evermore comprehensive cataloguing and phenotypic annotation of CRC-associated variants identified through sequencing approaches. This will have important clinical implications, particularly in areas such as risk stratification, public health and CRC prevention.

\section{BACKGROUND}

Colorectal carcinoma (CRC) is the third most common cancer worldwide, with approximately 1360600 new cases diagnosed in 2012. ${ }^{1}$ The majority of CRCs occur sporadically, but in 15\%$35 \%$ of patients, hereditary factors are important (reviewed in refs. 23 ). Here, we provide an update on the genetic basis of inherited predisposition to CRC. Currently known genetic factors include a group of genes associated with rare mendelian cancer syndromes, and a group of common lowpenetrance alleles that have been identified through association studies in large cohorts of patients with CRC and controls. We highlight recent findings and identify gaps in present knowledge, and consider how these may be addressed through genomic approaches.

\section{MENDELIAN COLORECTAL CANCER SYNDROMES}

Up to $5 \%$ of CRC occurs in the context of highly penetrant dominantly inherited syndromes (reviewed in ref. 2), and a much smaller proportion occurs in recessive syndromes (see online supplementary table S1). These syndromic disorders include the adenomatous polyposes-familial adenomatous polyposis (FAP), MUTYH-associated polyposis (MAP), NTHL1-associated polyposis, polymerase proofreading-associated polyposis and constitutional mismatch repair (MMR) deficiency syndrome; the hamartomatous polyposis syndromes-juvenile polyposis syndrome, PeutzJeghers syndrome and the PTEN hamartoma syndrome; hereditary mixed polyposis syndrome, in which patients have multiple polyps of different morphologies and Lynch syndrome (LS) when colorectal cancer usually develops in the absence of obvious polyposis (figures 1 and 2).

In these disorders, the risk of CRC in the absence of preventive measures is very high $(10 \%-$ $100 \%) .{ }^{4}$ The associated genes have been identified, and testing for inherited mutations has become routine in patients and families where these disorders are suspected, including predictive testing in asymptomatic family members to facilitate planning of surveillance and preventive measures. Guidelines are well established for the management of patients with many of these diseases, for example, the Mallorca Group guidelines for the management of $\mathrm{LS}^{5}$ and $\mathrm{FAP}^{6}$ and the American College of Gastroenterology guidelines for the management of LS. ${ }^{7}$ However, there is still a paucity of large prospective studies to inform robust estimates of cancer risk and assess the efficacy of surveillance and interventions.

The recent identification of colorectal adenoma and carcinoma predisposing mutations in DNA polymerase genes and in the base excision repair gene NTHL1 serve as a reminder that there are still likely to be gaps in our knowledge of rare highpenetrance genes, which predispose to colorectal cancer. Palles $e t \mathrm{al}^{8}$ identified heterozygous germline variants in POLE and POLD1 in individuals with a family history of multiple adenomas and CRC, but no detectable mutations in known polyposis-associated genes, including APC or MUTYH. The study employed whole-genome sequencing, linkage and association approaches. Two high-penetrance variants, POLE p.Leu424Val and POLD1 p.Ser478Asn, were localised to the proofreading (exonuclease) domains of these polymerases. POLE p.Leu424Val was subsequently also identified in 12 unrelated cases in a cohort of 3805 European individuals with colorectal cancer enriched for a family history of CRC, early onset disease and multiple adenomas. Ten individuals from two families were found to have the POLD1 p.Ser478Asn variant with a further individual identified in the validation phase. ${ }^{8}$ Tumours in these patients were microsatellite stable, but acquired base substitution mutations. More recently, the two germline mutations were studied in a further cohort of patients with unexplained familial and early onset CRC and/or polyposis. Valle et $a l^{9}$ investigated 858 such patients: POLE p.Leu424Val was identified as a de novo mutation in a patient with sporadic polyposis and CRC. While POLD1 


\section{Review}

Figure 1 H\&E microscopic images of colorectal polyps. (A) Tubular adenoma with low-grade dysplasia. (B)

Hyperplastic polyp: note the presence of glands in the centre of the image with a serrated/'tooth-like' appearance. (C) A Peutz-Jeghers polyp. The glands are separated by bundles of smooth muscle. (D) A juvenile polyp. Cystically dilated glands are present in an oedematous and inflamed stroma.
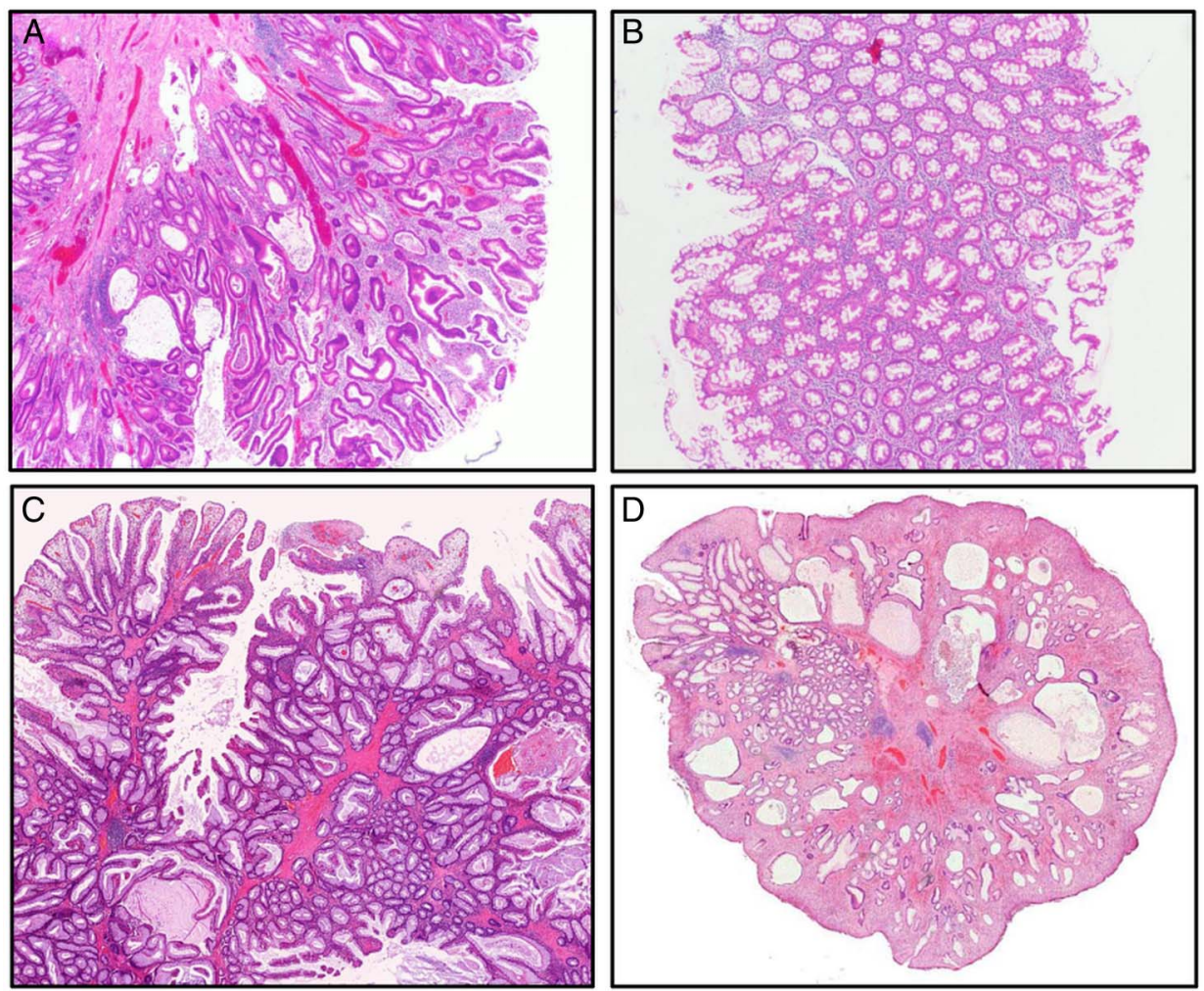

p.Ser478Asn was not observed, the group found a novel mutation, POLD1 c.1421T>C (p.Leu474Pro), in a family fulfilling the Amsterdam II criteria (that are used to identify families who may have LS), but whose members had MMR-proficient tumours. A similar study was carried out by Elsayed et al. ${ }^{10}$ They examined 1188 patients with familial CRC and polyposis for the two common mutations, and identified three patients $(0.25 \%)$ with the POLE p.Leu424Val variant. ${ }^{10}$ The tumours

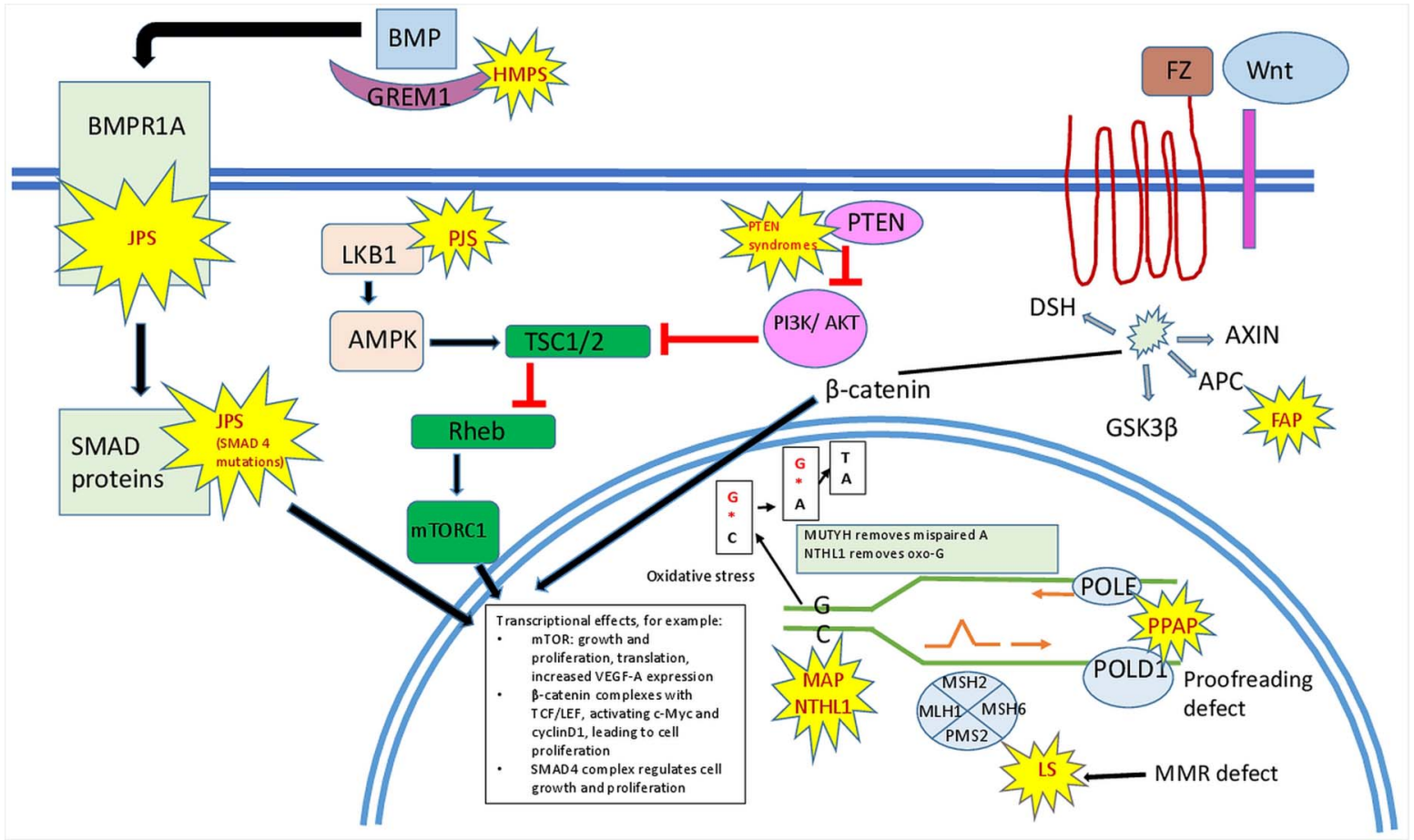

Figure 2 Diagram illustrating relationships between genes and signalling pathways involved in inherited colorectal cancer syndromes. FAP, familial adenomatous polyposis syndrome; HMPS, hereditary mixed polyposis syndrome; JPS, juvenile polyposis syndrome; LS, Lynch syndrome; MAP, MUTYH-associated polyposis; NTHL1, NTHL1-associated polyposis; PJS, Peutz-Jeghers syndrome; PPAP, polymerase proofreading-associated polyposis syndrome. 
from these patients were microsatellite unstable, and immunohistochemistry showed MSH6/MSH2 deficiency, although there were no germline mutations in the corresponding genes. ${ }^{10}$ Spier et $a l^{11}$ carried out targeted sequencing of POLD1, POLD2, POLD3, POLE, POLE2, POLE3 and POLE4 in 266 unrelated patients who had polyposis or who fulfilled Amsterdam criteria, but in whom no germline mutation had been identified in LS or other polyposis syndrome-associated genes. POLE p.Leu424Val was detected in four patients, and the group identified a further nine potentially pathogenic $P O L$ variants. Bellido et al ${ }^{12}$ studied the exonuclease domains of POLE and POLD1 in 441 patients with familial non-polyposis colorectal cancer and 88 patients with polyposis. They used massively parallel sequencing to identify seven novel or rare genetic variants. ${ }^{12}$

Very recently, Weren $e t a l^{13}$ applied whole exome sequencing in 51 patients with multiple colorectal adenomas who did not have identified mutations in APC or MUTYH. They found that seven members of three families had homozygous germline mutations in NTHL1. Tumours from affected individuals showed a significant increase in the proportion of C:G>T:A transitions, consistent with the predicted effects of homozygous loss-of-function mutations in NTHL1 on the accumulation of somatic mutations. Further studies of larger patient cohorts are required to characterise the newly recognised disorder NTHL1-associated polyposis.

While mutations in genes that are already known to be associated with polyposis syndromes can be identified in the majority of patients with many tens or hundreds of polyps, the extent to which unidentified changes in these genes account for the remainder is unclear. Alternatively, further currently unknown genes or other aetiological factors may be involved in some cases. Genes encoding components of pathways already implicated in CRC predisposition that regulate Wnt or BMP/TGF-B signalling, cell adhesion, ubiquitin-mediated proteolysis and DNA repair are further plausible functional candidates, as are genes which have a role in other cancer predisposition syndromes. Yurgelun et $a l^{14}$ have demonstrated that in a large cohort of patients with early onset colorectal cancer, $1.3 \%$ (6/ 457) had germline mutations in TP53, none of whom met the clinical criteria for Li-Fraumeni syndrome. This frequency is comparable with the prevalence of germline APC mutations in colorectal cancer. $^{14}$

\section{UNUSUAL MUTATIONAL MECHANISMS IN MENDELIAN COLORECTAL CANCER SYNDROMES}

Historical approaches that were employed for molecular genetic diagnosis such as Sanger sequencing and multiplex ligationdependent probe amplification have incomplete sensitivity for the detection of mutations in coding sequences, and diagnostic laboratories rarely test for point mutations in non-coding sequences, except at intron-exon boundaries. In one study of 171 patients with multiple colorectal adenomas in whom APC or MUTYH mutations had not been detected by Sanger sequencing, the $A P C$ coding region was retested using high resolution melt analysis leading to the detection of pathogenic heterozygous APC mutations in $10(6 \%)$ and mosaic APC mutations in two $(1 \%) .{ }^{15}$ Others have searched for and identified promoter mutations, deep intronic mutations, complex genomic rearrangements and mosaic mutations in a proportion of polyposis cases originally thought not to harbour mutations in APC or MUTYH. ${ }^{16-21}$ The application of next-generation sequencing to rapidly screen whole genomic loci at great depth overcomes many of the limitations of other laboratory techniques, but interpretation and functional characterisation of non-coding variants remains problematic.

Constitutional epimutation, the epigenetic silencing of an allele in normal somatic tissues, has been demonstrated to affect MLH1 or MSH2 in a number of patients with LS, mostly sporadic cases, with MMR-deficient tumours. ${ }^{22-25}$ A variety of sequence changes outside of the coding regions of the genes themselves has been shown to lead to promoter methylation and allele silencing. These include promoter mutations ${ }^{26}$ and a relatively frequent deletion in the $3^{\prime}$ end of the EPCAM gene that lies adjacent to $M S H 2$. This leads to transcriptional readthrough from EPCAM into MSH2 and MSH2 promoter methylation in the epithelial tissues in which EPCAM is expressed. ${ }^{27}$ (Constitutional epimutation has not been reported in other CRC syndromes).

Mosaicism, the presence of genetically distinct cell lines in the same individual, poses a particular challenge for mutation detection. Somatic mosaicism for APC mutations in which mutant alleles are present at lower frequency than expected in heterozygotes (ie, $<50 \%$ and often much lower) appears to be relatively common among patients with sporadic FAP. $^{17}$ Segmental somatic mosaicism in which the mutation is confined to specific body segments requires analysis of tissue from the affected area, and has been reported in patients with FAP who have had APC mutations identified in the affected part of the colon, but undetectable in other somatic tissues. ${ }^{28-30}$ The massively parallel nature of next-generation sequencing makes this approach very suitable for the detection of mutant alleles present at low frequency, ${ }^{31}$ but does not overcome problems of segmental mosaicism.

\section{SERRATED POLYPOSIS SYNDROME}

The aetiological basis of serrated polyposis syndrome (SPS) is currently unknown. Most hyperplastic, metaplastic or serrated polyps are small $(<1 \mathrm{~cm})$ sporadic lesions, but patients with SPS develop multiple polyps that may be large $(>1 \mathrm{~cm})$. The condition was first described in 1980 by Williams et al..$^{32}$ They observed seven patients, with a mean age of 37.4 years, who each had at least 50 colorectal polyps (then termed 'metaplastic polyps'). At that time, the authors concluded that 'it is impossible to deduce whether or not "metaplastic polyposis" is a distinct entity. There is no good evidence that it is familial in this small series, but the appearance of numerous metaplastic polyps of an unusually large size and configuration, predominantly in young males, might suggest a specific disease'. The identification of further similar patients led Burt and Jass to propose a definition for 'hyperplastic polyposis syndrome' in the $2000 \mathrm{WHO}$ classification of tumours. ${ }^{3}$ This definition was modified in 2010, and the disease was renamed serrated polyposis syndrome. ${ }^{34}$ Current diagnostic criteria for SPS require a patient to have:

1. at least five serrated (hyperplastic) polyps proximal to the sigmoid colon, two of which are $>10 \mathrm{~mm}$ in diameter or;

2. any number of serrated polyps proximal to the sigmoid colon in an individual who has a first-degree relative with serrated polyposis or;

3. more than 20 serrated polyps of any size distributed throughout the colon.

It was thought that SPS affected 1 in 3000 individuals between the ages of 55 and 64 years (reviewed in ref. 35) and as many as 1 in 151 patients having a colonoscopy following a positive faecal occult blood test (reviewed in ref. 36). SPS shows no sex predilection, and the mean age of diagnosis is 55 
years. ${ }^{37} 38$ In addition to hyperplastic lesions, there are often conventional adenomas present in the bowel. ${ }^{36}$

Patients with SPS seem to fall into one of two 'molecular groups' (reviewed in refs. 37 38), one with relatively few large right-sided polyps, which harbour BRAF mutations, the other with many small left-sided lesions, which often harbour KRAS mutations (reviewed in refs. 37 38). The combined incidence of KRAS and BRAF mutations ranges from $64 \%$ to $75 \%$ (reviewed in refs. 37 39). Polyps with epithelial dysplasia have higher rates of these mutations (90\%) (reviewed in ref. 37). Some patients may have a combination of left-sided and right-sided lesions. ${ }^{38}$

Patients with SPS are at an increased risk of developing CRC, which typically occurs between 50 and 60 years of age (reviewed in ref. 34). Malignancy is associated with a larger number of polyps, the presence of dysplasia (reviewed in refs. 3740 ), and the existence of conventional adenomas in addition to hyperplastic polyps. ${ }^{35}$ The estimated incidence of CRC in patients with SPS varies from $14 \%$ to $58 \%$ (reviewed in refs. 35 40-42). Interestingly, a large proportion of CRCs seen in patients with SPS do not develop through the 'serrated pathway of carcinogenesis', driven by BRAF mutation. ${ }^{35}$ The cancers show various molecular changes, including those more likely to be associated with the traditional adenoma-carcinoma pathway, for example, $\beta$-catenin activation and/or overexpression of p53. ${ }^{35}$

SPS may be a genetic disease, but if so, the mode of inheritance is unclear and recessive and dominant models have both been suggested (reviewed in ref. 37). SPS could be the result of a predisposition to promoter hypermethylation (reviewed in refs. 37 43), and some studies have reported hypermethylation in apparently normal colonic mucosa in patients with SPS (reviewed in ref. 44).

\section{LOW-PENETRANCE ALLELES AND POLYGENIC PREDISPOSITION}

Genome-wide association studies (GWAS) have so far identified approximately 40 CRC susceptibility loci, each of which is associated with a small increase in CRC risk (see online supplementary table S2). Variants at these loci are not strictly 'mutations', and may alter gene expression or function or, more usually, be in linkage disequilibrium with the mechanistic variant. On the basis of an additive model, the 10 CRC loci initially identified were thought to collectively account for approximately $6 \%$ of excess familial risk. ${ }^{45}$ However, it is clear that such an additive model cannot adequately explain increases in disease risk, ${ }^{46}$ and it appears that the combined effect of such variants follows a multiplicative (log additive) risk model (reviewed in ref. 47). The risks associated with each of the variants have been much too small for translation to testing in clinical practice, but the development of algorithms estimating cumulative risks associated with carriage of multiple alleles are expected to lead to clinical application, as has already been proposed in the context of breast cancer. ${ }^{48}$ Dunlop et $a l^{49}$ sought to assess the feasibility of CRC risk prediction using common genetic variant data combined with other risk factors. They used binary logistic regression to assess the combined effects of age, gender, family history and genotypes at 10 susceptibility loci that confer only small CRC risks. They found that while genotype data provided additional information that complemented age, gender and family history as risk factors, clinically useful individualised genetic risk prediction was not currently feasible. However, it was proposed that such risk prediction models might help to identify high-risk groups that could benefit from public health measures to prevent CRC.

\section{INTERMEDIATE PENETRANCE ALLELES}

While $15 \%-35 \%$ of colorectal cancers are believed to occur in the context of significant inherited predisposition (reviewed in ref. 2 3), currently identified genetic factors can probably only account for up to $10 \%$ of CRCs. One type of currently missing heritability is likely to be mutations (variants) of intermediate penetrance, that is, those which confer a relative cancer risk from 1.5 to $5 .^{50}$ In general, the allele frequencies of such mutations will be too low to have been identified in GWAS and penetrance too low to have been identified in traditional family linkage studies. However, as sequencing-based approaches have been applied, such mutations have already been identified in patients and families with breast cancer, in genes such as CHEK2, ATM, PALB2 and BRIPI, ${ }^{50}$ and it is anticipated that sequencing approaches in patients and families with CRC will identify comparable mutations that predispose to CRC. For example, a very recent report suggests that mutations in the DNA repair gene FAN1 may predispose to colorectal cancer. ${ }^{51}$

\section{CONCLUSION}

CRC is the third most common cancer worldwide, ${ }^{1}$ and inherited factors are important in a significant proportion of cases. Previous genetic and genomic studies have identified the basis of only a small part of this heritability. Clinical application of testing for highly penetrant and therefore high-risk mutations has become an established part of managing CRC, and is enshrined in international guidelines. ${ }^{5-7}$ By contrast, the incomplete picture of the genomic architecture of inherited predisposition to CRC has so far precluded the clinical application of testing for low-penetrance variants. It is expected that identification of the missing heritable component of CRC will be resolved through evermore comprehensive cataloguing and phenotypic annotation of CRC-associated variants identified through sequencing approaches. Clinical applications in public health and CRC prevention may follow.

Acknowledgements The authors would like to thank Professor Geraint Williams for his help in identifying suitable microscopic images of colorectal polyps and the Wales Gene Park and Health and Care Research Wales (previously NISCHR) for support for the authors' work.

Contributors All authors have been involved with writing the review article and with draft revision. All authors give their approval of the final version, and are accountable for its contents.

Competing interests None declared.

Provenance and peer review Not commissioned; externally peer reviewed.

\section{REFERENCES}

1 Cancer Research UK. http://www.cancerresearchuk.org/health-professional/ cancer-statistics/worldwide-cancer/incidence\#heading-One (accessed 02/06/2015).

2 Mishra N, Hall J. Identification of patients at risk for hereditary colorectal cancer. Clin Colon Rectal Surg 2012;25:67-82.

3 Burt R. Inheritance of colorectal cancer. Drug Discov Today Dis Mech 2007:4:293-300.

4 Dunlop MG. Guidance on gastrointestinal surveillance for hereditary non-polyposis colorectal cancer, familial adenomatous polyposis, juvenile polyposis and Peutz-Jeghers syndrome. Gut 2002;51(Suppl V):v21-7.

5 Vasen HF, Blanco I, Aktan-Collan K, Gopie JP, Alonso A, Aretz S, Bernstein I, Bertario L, Burn J, Capella G, Colas C, Engel C, Frayling IM, Genuardi M, Heinimann K, Hes FJ, Hodgson SV, Karagiannis JA, Lalloo F, Lindblom A, Mecklin JP, Møller P, Myrhoj T, Nagengast FM, Parc Y, Ponz de Leon M, Renkonen-Sinisalo L, Sampson JR, Stormorken A, Sijmons RH, Tejpar S, Thomas HJ, Rahner N, Wijnen JT, Järvinen HJ, Möslein G, Mallorca group. Revised guidelines for the clinical management of Lynch syndrome (HNPCC): recommendations by a group of European experts. Gut 2013;62:812-23.

6 Vasen HF, Möslein G, Alonso A, Aretz S, Bernstein I, Bertario L, Blanco I, Bülow S, Burn J, Capella G, Colas C, Engel C, Frayling I, Friedl W, Hes FJ, Hodgson $S_{1}$ Järvinen $H$, Mecklin JP, Møller P, Myrhøi T, Nagengast FM, Parc Y, Phillips R, Clark 
SK, de Leon MP, Renkonen-Sinisalo L, Sampson JR, Stormorken A, Tejpar S, Thomas HJ, Wijnen J. Guidelines for the clinical management of familial adenomatous polyposis (FAP). Gut 2008;57:704-13.

7 Giardiello FM, Allen Jl, Axilbund JE, Boland CR, Burke CA, Burt RW, Church JM, Dominitz JA, Johnson DA, Kaltenbach T, Levin TR, Lieberman DA, Robertson DJ, Syngal S, Rex DK. Guidelines on genetic evaluation and management of Lynch syndrome: a consensus statement by the US multi-society task force on colorectal cancer. Am J Gastroenterology 2014;109:1159-79.

8 Palles C, Cazier JB, Howarth KM, Domingo E, Jones AM, Broderick P, Kemp Z, Spain SL, Guarino E, Salguero I, Sherborne A, Chubb D, Carvajal-Carmona LG, Ma Y, Kaur K, Dobbins S, Barclay E, Gorman M, Martin L, Kovac MB, Humphray S, CORGI Consortium; WGS500 Consortium, Lucassen A, Holmes CC, Bentley D, Donnelly P, Taylor J, Petridis C, Roylance R, Sawyer EJ, Kerr DJ, Clark S, Grimes J, Kearsey SE, Thomas HJ, McVean G, Houlston RS, Tomlinson I. Germline mutations affecting the proofreading domains of POLE and POLD1 predispose to colorectal adenomas and carcinomas. Nat Genet 2013;45:136-44.

9 Valle L, Hernández-Illán E, Bellido F, Aiza G, Castillejo A, Castillejo MI, Navarro M, Seguí N, Vargas G, Guarinos C, Juarez M, Sanjuán X, Iglesias S, Alenda C, Egoavil C, Segura Á, Juan MJ, Rodriguez-Soler M, Brunet J, González S, Jover R, Lázaro C, Capellá G, Pineda M, Soto JL, Blanco I. New insights into POLE and POLD1 germline mutations in familial colorectal cancer and polyposis. Hum Mol Genet 2014;23:3506-12.

10 Elsayed FA, Kets CM, Ruano D, van der Akker B, Mensenkamp AR, Schrumpf M, Nielson M, Winjen JT, Tops CM, Ligtenberg MJ, Vasen HFA, Hes FJ, Morreau H, van Wezel T. Germline variants in POLE are associated with early onset mismatch repair deficient colorectal cancer. Eur J Hum Genet 2015;23:1080-4.

11 Spier I, Holzapfel S, Altmüller J, Zhao B, Horpaopan S, Vogt S, Chen S, Morak M, Raeder S, Kayser K, Stienen D, Adam R, Nürnberg P, Plotz G, Holinski-Feder E, Lifton RP, Thiele H, Hoffmann P, Steinke V, Aretz S. Frequency and phenotypic spectrum of germline mutations in POLE and seven other polymerase genes in 266 patients with colorectal adenomas and carcinomas. Int J Cancer 2015:137:320-31.

12 Bellido F, Pineda M, Aiza G, Valdés-Mas R, Navarro M, Puente DA, Pons T, González S, Iglesias S, Darder E, Piñol V, Soto JL, Valencia A, Blanco I, Urioste M, Brunet J, Lázaro C, Capellá G, Puente XS, Valle L. POLE and POLD1 mutations in 529 kindred with familial colorectal cancer and/or polyposis: review of reported cases and recommendations for genetic testing and surveillance. Genet Med 2015. Published Online First: 2 Jul 2015. doi:10.1038/gim.2015.75

13 Weren RD, Ligtenberg MJ, Kets CM, de Voer RM, Verwiel ET, Spruijt L, van Zelst-Stams WA, Jongmans MC, Gilissen C, Hehir-Kwa JY, Hoischen A, Shendure J, Boyle EA, Kamping EJ, Nagtegaal ID, Tops BB, Nagengast FM, Geurts van Kessel A, van Krieken JH, Kuiper RP, Hoogerbrugge N. A germline homozygous mutation in the base-excision repair gene NTHL1 causes adenomatous polyposis and colorectal cancer. Nat Genet 2015:47:668-71.

14 Yurgelun MB, Masciari S, Joshi VA, Mercado RC, Lindor NM, Gallinger S, Hopper JL, Jenkins MA, Buchanan DD, Newcomb PA, Potter JD, Haile RW, Kucherlapati R, Syngal S, Colon Cancer Family Registry. Germline TP53 mutations in patients with early-onset colorectal cancer in the colon cancer family registry. JAMA Oncol 2015;1:214-21.

15 Out AA, van Minderhout IJ, van der Stoep N, van Bommel LS, Kluijt I, Aalfs C, Voorendt M, Vossen RH, Nielsen M, Vasen HF, Morreau H, Devilee P, Tops CM, Hes FJ. High-resolution melting (HRM) re-analysis of a polyposis patients cohort reveals previously undetected heterozygous and mosaic $A P C$ gene mutations. Fam Cancer 2015; 14:247-57

16 Hes FJ, Nielsen M, Bik EC, Konvalinka D, Wijnen JT, Bakker E, Vasen HF, Breuning $\mathrm{MH}$, Tops CM. Somatic APC mosaicism: an underestimated cause of polyposis coli. Gut 2008:57:71-6.

17 Aretz S, Stienen D, Friedrichs N, Stemmler S, Uhlhaas S, Rahner N, Propping P, Friedl W. Somatic APC mosaicism: a frequent cause of familial adenomatous polyposis (FAP). Hum Mutat 2007;28:985-92.

18 Rohlin A, Engwall Y, Fritzell K, Göransson K, Bergsten A, Einbeigi Z, Nilbert M, Karlsson P, Björk J, Nordling M. Inactivation of promoter 1B of APC causes partial gene silencing: evidence for a significant role of the promoter in regulation and causative of familial adenomatous polyposis. Oncogene 2011;30:4977-89.

19 Spier I, Horpaopan S, Vogt S, Uhlhaas S, Morak M, Stienen D, Draaken M, Ludwig M, Holinski-Feder E, Nöthen MM, Hoffmann P, Aretz S. Deep intronic APC mutations explain a substantial proportion of patients with familial or early-onset adenomatous polyposis. Hum Mutat 2012:33:1045-50.

20 Charames GS, Ramyar L, Mitri A, Berk T, Cheng H, Jung J, Bocangel P, Chodirker $B$, Greenberg C, Spriggs E, Bapat B. A large novel deletion in the APC promoter region causes gene silencing and leads to classical familial adenomatous polyposis in a Manitoba Mennonite kindred. Hum Genet 2008;124:535-41.

21 Kadiyska TK, Todorov TP, Bichev SN, Vazharova RV, Nossikoff AV, Savov AS, Mitev VI. APC promoter 1B deletion in familial polyposis-implications for mutation-negative families. Clin Genet 2014;85:452-7.

22 Goel A, Nguyen TP, Leung HC, Nagasaka T, Rhees J, Hotchkiss E, Arnold M, Banerji P, Koi M, Kwok CT, Packham D, Lipton L, Boland CR, Ward RL, Hitchins MP. De novo constitutional MLH1 epimutations confer early-onset colorectal cancer in two new sporadic Lynch syndrome cases, with derivation of the epimutation on the paternal allele in one. Int J Cancer 2011;128:869-78.

23 Crépin M, Dieu MC, Lejeune S, Escande F, Boidin D, Porchet N, Morin G, Manouvrier S, Mathieu M, Buisine MP. Evidence of constitutional MLH1 epimutation associated to transgenerational inheritance of cancer susceptibility. Hum Mut 2012;33:180-8.

24 Hitchins MP. The role of epigenetics in Lynch Syndrome. Fam Cancer 2013:12:189-205.

25 Ward RL, Dobbins T, Lindor NM, Rapkins RW, Hitchins MP. Identification of constitutional MLH1 epimutations and promoter variants in colorectal cancer patients from the Colon Cancer Family Registry. Genet Med 2013;15:25-35.

26 Morak M, Koehler U, Schackert HK, Steinke V, Royer-Pokora B, Schulmann K, Kloor M, Höchter W, Weingart J, Keiling C, Massdorf T, Holinski-Feder E, German HNPCC consortium. Biallelic MLH1 SNP CDNA expression or constitutional promoter methylation can hide genomic rearrangements causing Lynch syndrome. J Med Genetic 2011;48:513-19.

27 Ligtenberg MJ, Kuiper RP, Chan TL, Goossens M, Hebeda KM, Voorendt M, Lee TY, Bodmer D, Hoenselaar E, Hendriks-Cornelissen SJ, Tsui WY, Kong CK, Brunner HG, van Kessel AG, Yuen ST, van Krieken JH, Leung SY, Hoogerbrugge N. Heritable somatic methylation and inactivation of MSH2 in families with Lynch syndrome due to deletion of the $3^{\prime}$ exons of TACSTD1. Nat Genetic 2009;41:112-17.

28 Mandl M, Kadmon M, Sengteller M, Caspari R, Propping P, Friedl W. A somatic mutation in the adenomatous polyposis coil (APC) gene in peripheral blood cellsimplications for predictive diagnosis. Hum Mol Genet 1994;3:1009-11.

29 Farrington SM, Dunlop MG. Mosaicism and sporadic familial adenomatous polyposis. Am J Hum Genetics 1999;64:653-8.

30 Davidson S, Leshanski L, Rennert G, Eidelman S, Amikam D. Maternal mosaicism for a second mutational event—a novel deletion —in a familial adenomatous polyposis family harboring a new germ-line mutation in the alternatively spliced-exon 9 region of APC. Hum Mutat 2002;19:83-4.

31 Rohlin A, Wernersson J, Engwall Y, Wiklund L, Björk J, Nordling M. Parallel sequencing used in detection of mosaic mutations: comparison with four diagnostic DNA screening techniques. Hum Mutat 2009;30:1012-20.

32 Williams GT, Arthur JF, Bussey HJ, Morson BC. Metaplastic polyps and polyposis of the colorectum. Histopathology 1980;4:155-70.

33 Burt R, Jass JR. Hyperplastic polyposis. In: Hamilton SR, Aatonen SA, eds. WHO classification of tumours. Berlin: Springer-Verlag, 2000:135-6.

34 Snover DC, Ahnen DJ, Burt RW, Odze RD. Serrated polyps of the colon and rectum and serrated ("hyperplastic") polyposis. In: Bosman ST, Carneiro F, Hruban RH, Theise ND, eds. WHO classification of tumours of the digestive system. Berlin: Springer-Verlag, 2010:160-5.

35 Rosty C, Walsh MD, Walters RJ, Clendenning M, Pearson SA, Jenkins MA, Win AK, Hopper JL, Sweet K, Frankel WL, Aronson M, Gallinger S, Goldblatt J, Tucker K, Greening S, Gattas MR, Woodall S, Arnold J, Walker NI, Parry S, Young JP, Buchanan DD. Multiplicity and molecular heterogeneity of colorectal carcinomas in individuals with serrated polyposis. Am J Surg Pathol 2013;37:434-42.

36 Rosty C, Hewett DG, Brown IS, Leggett BA, Whitehall VL. Serrated polyps of the large intestine: current understanding of diagnosis, pathogenesis, and clinical management. J Gastroenterol 2013;48:287-302.

37 Guarinos C, Sánchez-Fortún C, Rodríguez-Soler M, Alenda C, Payá A, Jover R. Serrated polyposis syndrome: molecular, pathological and clinical aspects. World $\rfloor$ Gastroenterol 2012;18:2452-61.

38 Kalady MF, Jarrar A, Leach B, LaGuardia L, O'Malley M, Eng C, Church JM. Defining phenotypes and cancer risk in hyperplastic polyposis syndrome. Dis Colon Rectum 2011:54:164-70.

39 Carvajal-Carmona LG, Howarth KM, Lockett M, Polanco-Echeverry GM, Volikos E, Gorman M, Barclay E, Martin L, Jones AM, Saunders B, Guenther T, Donaldson A, Paterson J, Frayling I, Novelli MR, Phillips R, Thomas HJ, Silver A, Atkin W, Tomlinson IP. Molecular classification and genetic pathways in hyperplastic polyposis syndrome. J Pathol 2007;212:378-85.

40 Yeoman A, Young J, Arnold J, Jass J, Parry S. Hyperplastic polyposis in the New Zealand population: a condition associated with increased colorectal cancer risk and European ancestry. N Z Med J 2007;120:U2827.

41 Hyman NH, Anderson P, Blasyk H. Hyperplastic polyposis and the risk of colorectal cancer. Dis Colon Rectum 2004;47:2101-4.

42 Lage P, Cravo M, Sousa R, Chaves P, Salazar M, Fonseca R, Claro I, Suspiro A, Rodrigues P, Raposo H, Fidalgo P, Nobre-Leitão C, et al. Management of Portuguese patients with hyperplastic polyposis and screening of at-risk first-degree relatives: a contribution for future guidelines based on a clinical study. Am J Gastroenterol 2004;99:1779-84.

43 Leggett $B$, Whitehall V. Role of the serrated pathway in colorectal cancer pathogenesis. Gastroenterology 2010;138:2088-100.

44 Young J and Jass JR. The case for a genetic predisposition to serrated neoplasia in the colorectum: hypothesis and review of the literature. Cancer Epidemiol Biomarkers Prev 2006; (10):1778-84.

45 COGENT Study Houlston RS, Webb E, Broderick P, Pittman AM, Di Bernardo MC, Lubbe S, Chandler I, Vijayakrishnan J, Sullivan K, Penegar S; Colorectal Cancer Association Study Consortium, Carvajal-Carmona L, Howarth K, Jaeger E, Spain SL, 


\section{Review}

Walther A, Barclay E, Martin L, Gorman M, Domingo E, Teixeira AS; CoRGI Consortium, Kerr D, Cazier JB, Niittymäki I, Tuupanen S, Karhu A, Aaltonen LA, Tomlinson IP, Farrington SM, Tenesa A, Prendergast JG, Barnetson RA, Cetnarskyj R, Porteous ME, Pharoah PD, Koessler T, Hampe J, Buch S, Schafmayer C, Tepel J, Schreiber S, Völzke H, Chang-Claude J, Hoffmeister M, Brenner H, Zanke BW, Montpetit A, Hudson TJ, Gallinger S, Campbell H, Dunlop MG. Meta-analysis of genome-wide association data identifies four new susceptibility loci for colorectal cancer. Nat Genet 2008;401426-35.

46 Wray NR, Goddard ME. Multi-locus models of genetic risk of disease. Genome Medicine 2010;2:10.

47 Kundu S, Mihaescu R, Meijer CM, Bakker R, Janssens AC. Estimating the predictive ability of genetic risk models in simulated data based on published results from genome-wide association studies. Front Genet 2014;5:179.

48 Pharoah PD, Antoniou AC, Easton DF, Ponder BA. Polygenes, risk prediction and targeted prevention of breast cancer. N Engl J Med 2008;358:2796-803.

49 Dunlop MG, Tenesa A, Farrington SM, Ballereau S, Brewster DH, Koessler T, Pharoah P, Schafmayer C, Hampe J, Völzke H, Chang-Claude J, Hoffmeister M,
Brenner $H$, von Holst S, Picelli S, Lindblom A, Jenkins MA, Hopper JL, Casey G, Duggan D, Newcomb PA, Abulí A, Bessa X, Ruiz-Ponte C, Castellví-Bel S, Niittymäki I, Tuupanen S, Karhu A, Aaltonen L, Zanke B, Hudson T, Gallinger S, Barclay E, Martin L, Gorman M, Carvajal-Carmona L, Walther A, Kerr D, Lubbe S, Broderick P, Chandler I, Pittman A, Penegar S, Campbell H, Tomlinson I, Houlston RS. Cumulative impact of common genetic variants and other risk factors on colorectal cancer risk in 42103 individuals. Gut 2013;62:871-81.

50 Apostolou P, Fostira F. Hereditary breast cancer: the era of new susceptibility genes. Biomed Res Int 2013;2013:747318.

51 Segui N, Mina LB, Lázaro C, Sanz-Pamplona R, Pons T, Navarro M, Bellido F, López-Doriga A, Valdés-Mas R, Pineda M, Guinó E, Vidal A, Soto JL, Caldés T, Durán $M$, Urioste $M$, Rueda $D$, Brunet J, Balbín $M$, Blay $P$, Iglesias $S$, Garré $P$, Lastra E, Sánchez-Heras AB, Valencia A, Moreno V, Pujana MA, Villanueva A, Blanco I, Capellá G, Surrallés J, Puente XS, Valle L. Germline Mutations in FAN1 Cause Hereditary Colorectal Cancer by Impairing DNA Repair. Gastroenterology 2015 Jun 5. pii: S0016-5085(15)00783-0. doi:10.1053/j.gastro.2015.05.056. [Epub ahead of print]. 


\section{IG Inherited predisposition to colorectal cancer: towards a more complete picture}

Emma Short, Laura E Thomas, Joanna Hurley, Sian Jose and Julian R Sampson

J Med Genet published online August 21, 2015

Updated information and services can be found at:

http://jmg.bmj.com/content/early/2015/08/21/jmedgenet-2015-103298

\section{These include:}

Supplementary Material

References

Email alerting service
Supplementary material can be found at:

http://jmg.bmj.com/content/suppl/2015/08/21/jmedgenet-2015-103298 .DC1.html

This article cites 45 articles, 7 of which you can access for free at: http://jmg.bmj.com/content/early/2015/08/21/jmedgenet-2015-103298 \#BIBL

Receive free email alerts when new articles cite this article. Sign up in the box at the top right corner of the online article.

\section{Notes}

To request permissions go to:

http://group.bmj.com/group/rights-licensing/permissions

To order reprints go to:

http://journals.bmj.com/cgi/reprintform

To subscribe to BMJ go to:

http://group.bmj.com/subscribe/ 